\title{
Living the Teaching Practicum Within Dichotomies: The Story From Within When Implementing ICTs in the English Language Classroom
}

\section{Viviendo la práctica docente desde las dicotomías: la historia desde adentro cuando se implementan TIC en el salón de clase de inglés*}

\author{
Sandra Viviana Pinzón Capador \\ svpinzonc@correo.udistrital.edu.co \\ Carmen Helena Guerrero Nieto \\ chguerreron@udistrital.edu.co \\ Universidad Distrital Francisco José de Caldas, Bogotá, Colombia
}

This article reports the results of an introspective research conducted by a student-teacher and her advisor. Both met regularly over a period of one year and a half as part of the student-teacher academic work for the Research I class. As a result of their conversation the student-teacher and her advisor decided to document the former's experience during her teaching practicum as she was trying to implement an innovation using $\mathrm{m}$-learning in a public school in Bogotá. The analysis of data (narrative introspection, introspective interview, and lesson plans) shows that the student-teacher lived her teaching practicum within dichotomies in three dimensions we named negotiating between epistemologies, making up for logistic/technological flaws, and mending the self: between frustration and achievement.

Key words: Innovation, practicum, pre-service teacher, technology.

Received: January 31, 2018. Accepted: May 28, 2018.

How to cite this article (APA 6th ed.):

Pinzón Capador, S. V., \& Guerrero Nieto, C. H. (2018). Living the teaching practicum within dichotomies:

The story from within when implementing ICTs in the English language classroom. HOW, 25(2), 69-89. https://doi.org/10.19183/how.25.2.459.

This article is licensed under a Creative Commons Attribution-NonCommercial-NoDerivatives 4.0 International License. License Deed can be consulted at https://creativecommons.org/licenses/by-nc-nd/4.0/. 
Este articulo reporta los resultados de un estudio introspectivo llevado a cabo por una docente de inglés en formación y su directora de monografía. Ambas se reunieron regularmente durante un año y medio como parte del trabajo académico en la clase Investigación I de la docente en formación. Como resultado de sus conversaciones ambas decidieron documentar la experiencia de la docente de inglés en formación durante su práctica mientras trataba de llevar a cabo una innovación usando aprendizaje móvil en un colegio distrital de Bogotá. El análisis de los datos (introspección narrativa, entrevista introspectiva y planes de clase) muestra que la docente en formación vivió su práctica entre dicotomías en tres dimensiones: negociación epistemológica, solucionar los problemas logísticos y tecnológicos, y remendar el yo: entre la frustración y la satisfacción.

Palabras clave: docente en formación, innovación, practica, tecnología.

\section{Introduction}

Walking the road towards becoming a teacher is a journey full of bumps where the one who walks needs to clear the road, fall, get up, experience joy, and suffer. The small-scale research reported here shows this path from the introspection of a student-teacher with the help of her research advisor. We think this study is relevant for various reasons, being the main one that most studies reporting on student-teachers are written from the perspective and voice of the researcher. Many researchers have reported the results of conducting innovation using technology in the classroom pointing at the benefits and constraints. This study helps to feed into that body of knowledge in the sense that it is easy to demand the inclusion of information and communications technologies (ICTs) in teachers' practices but the realities of Colombian contexts need to be considered when making such demands. Additionally, having the voice of this student-teacher about her struggles helps teacher educators reflect on how we can serve better the needs and interests of our students. In the first section, we will discuss some previous studies in the field of teaching practicum. Then, we will bring up some relevant literature to inform the study. Next, following a semi-narrative style, we present the description of the pedagogical intervention, and we close this report with our findings and conclusions.

\section{Other Paths, Other Walkers}

In our search for studies in the same area we developed this small-scale research, published in Colombian journals; we found that all but one are reported from the voice of the researcher, and not from the voice of student-teachers. We categorized the studies into three main groups: A first group of studies reports on student-teachers' instructional classroom management. For example, Castro and López (2014) examined the strategies used by four pre-service teachers from Universidad de Tolima to facilitate the development of the communicative skills of their students. The researchers found that the strategies work 
depending on the way pre-service teachers use them. In another research project conducted by Macías and Sánchez (2015), 34 pre-service teachers face their class management helped by their supervisors and the cooperating teachers. This study demonstrates that class management experiences influence pre-service teacher performance and shows how preservice teachers use their intuition to handle those situations.

A second group of studies take interest in pre-service teachers' beliefs. Aguirre (2014) explores the role beliefs play on pedagogical and emotional aspects. This research was carried out with six pre-service teachers from a private university in Bogotá and the researcher found that pre-service teachers' beliefs influence their performance because they feel a connection with their students and are motivated to solve students' needs. Another research task on pre-service teacher beliefs was developed by Suarez and Basto (2017) in which they tackle the way a pre-service teacher believes in change through the practicum, due to the lack of motivation and external factors. By the same token, the study by Cota and Ruiz-Esparza (2012), whose population was made up of 14 student-teachers, explores how beliefs emerge and how they influence pre-service teachers' performance. The researchers found that those beliefs are bound to the instruction received in their classes at school and in the practicum.

A third group of studies is made up of exploring how student-teachers use technology innovations. In the research conducted by Herrera, Cruz, and Sandoval (2014) in a university in Mexico, student-teachers implemented the use of portable devices in order to improve students' performance in the English class and found that it is a significant and efficient tool for learning because students feel enthusiastic to participate. In the research carried out by Espitia and Kwinta (2012), they implemented the Buddy System, a system that helps to promote online interaction among students of the English courses in Universidad de la Sabana in Colombia. This system facilitated online interaction and made students become aware of their English learning process.

In a different take on student-teachers, Quintero (2016) examined the way social factors influence the performance of nine pre-service teachers of Universidad Distrital. The researcher implemented life stories in order to collect pre-service teachers' narratives in order to understand how they construct themselves as teachers.

As mentioned earlier, all these studies have a common voice: that of the researcher. The only research report that is written from the voice of the student-teacher is the one by Usma and Frodden (2003) in which a novice-teacher and his advisor engage in reflection about his process of becoming a teacher at a school in Medellin. The research report presented in this article aims at capturing the perspective of the student teacher as it unfolds from her interaction with her advisor. 


\section{Roads Already Crossed}

This section discusses three relevant topics: teaching practicum, innovation, and mobile learning.

\section{Teaching Practicum}

Teaching practicum has been defined as the application of pedagogy in a meaningful context: the classroom (Roland \& Beckford, 2010). Freeman and Johnson (1998) argue that a real context is a must for pre-service teachers to bring their own interpretation of the teaching itself. The teaching practicum then constitutes an opportunity for pre-service teachers to be in contact with real context and to enrich it with social and cultural aspects they might incorporate into their teaching process.

According to Halverson (2004), during the teaching practicum pre-service teachers need to develop Phronesis or practical wisdom, an Aristotelian term which describes the ability to adjust some knowledge according to the context where it will be used. In order to understand Phronesis or practical wisdom, the author explains two key concepts: episteme $e^{1}$ and techne. ${ }^{2}$ The episteme is the kind of knowledge needed depending on the context and the techne refers to the knowledge to create something; the joining of both helps the pre-service teacher to perform in an effective way in any context.

To a great extent, pre-service teacher preparation programs have followed Shulman's $(1986,1987)$ seminal ideas on teachers' knowledge base. He categorizes what teachers should know as follows: content knowledge, general pedagogical knowledge, curriculum knowledge, pedagogical content knowledge, knowledge of learners, knowledge of educational context, and knowledge of educational ends. In a study conducted by Castañeda-Trujillo (2017) in which he examined the study plans of 22 English teaching programs from public and private Colombian universities, he showed there is a heavy weight on content knowledge and general pedagogical knowledge but very little weight on research and on teaching practicum (less than 10\% each of the study plans). This allows us to conclude that pre-service teacher preparation programs are still located within the passive technician and reflexive practitioner models (Kumaravadivelu, 2003). In the former, content knowledge is the most important and teachers are supposed to follow the prescriptions given by experts. The latter includes other sources of knowledge that come form experience and research. Yet, pre-service teacher preparation programs should move forward towards the transformative intellectual,

Philosophy, scientific knowledge, a system of understanding.

An art, skill, or craft; a technique, principle, or method by which something is achieved or created (Flyvbjerg, n.d.). 
the third model proposed by Kumaravadivelu (2003) where teachers (pre-service in this case) are considered as intellectuals who are able to think and act critically upon their context.

We have not got that far, and in terms of the teaching practicum there are three main models (Day, n.d.): (a) the apprentice-expert model where the pre-service teacher works closely under the guidance of an expert and learning happens through "observation, instruction, and practice" (Day, n.d., p. 5); (b) the rationalist model where students acquire theoretical knowledge and at the moment of the practicum they have to apply it; and (c) the case studies model which implies the analysis and discussions of real teaching cases-this model has not been widely used. Loughran and Hamilton (2016) add the laboratory model in which the preservice teacher needs to observe and analyze classes alone in order to develop her/his own understanding on how to teach a class. This model has been mainly implemented during the teaching practicum because the pre-service teacher is not yet in "action" and it permits the discussion and reflection on many issues that emerge in the classroom.

The undergraduate program where one of the researchers is enrolled, follows the laboratory model, and offers the teaching practicum starting in the fifth semester and ending in the eighth semester (in fifth and sixth semesters pre-service teachers do their teaching practicum in elementary school; seventh and eighth in secondary school in public schools).

\section{Innovation in English Language Teaching}

Rogers (1995) defines innovation in education as an idea or object that is seen as new for a person or for a group of people. When the new idea or object is presented, people determine if they adopt it or not. In order to adopt it, they must take into account five characteristic: relative advantage (how is it better), compatibility (how coherent it is with the values and experiences), complexity (how people understand it), trialability (the possibility to try in a shorter span), and observability (how the results are visible). If the innovative idea or object achieves those characteristics its adoption will be easier by the population and it will be developed.

Additionally, Rimari (n.d.) defines innovation as an external or internal force which aims to change, transform, or enhance the reality in the classroom. On the other hand, Huberman (1973) defines innovation as the creative selection, organization, and use of different materials in a new way in order to carry out a better way to achieve clearer goals. He sets some characteristics of innovation:

1. Innovation can only be appreciated in relation to the aims of the educational system where it will be applied.

2. Innovation considers the intensification or a major individualization of learning, a more professionalized education and more refined study plans. 
3. It implies changing the activities and attitudes of the educational community.

Rimari (n.d.) establishes the components that cause an innovation to occur. The first component is that the innovations appear because of the implementation of small changes inside the classroom; for instance, the implementation of a new text in the classroom. A second component is the popular impulse; it means that innovation is produced due to the change of ideas into the new ones based on people's beliefs. Finally, he explains that changes are mediated by an authority; it means that the changes could be implemented only if the authority in charge allows them.

Adding to these definitions, Barraza (2005) establishes that there is only one way to know the concept of innovation and that is by the knowledge of its domains; in innovation in education those domains are new and improvement. The new domain is understood as the things that have never been created; in this sense, innovations are unusual. The improvement domain has a relation to the last domain, when something new needs changes, it can be improved, which means that innovations in education are made to improve different educational factors such as methods or activities.

ICT innovation in English language teaching in Colombia. Teachers of English in Colombia have been innovating their teaching practices through the use of technology. In a general overview, through examining research reports published in the major journals in the country, we found that teachers engage in this type of innovation and while they acknowledge the advantages in language learning-teaching, they also point at the major constraints that have to do with infrastructure, connectivity, technological skills, and institutional support, to mention some. As examples, we can mention a study conducted by Galvis (2011) in which he explored the integration of computer technology in two English classes in a language center in Bogotá. He found that implementing ICTs in the classroom is complex due to four main aspects: feasibility, time, user-friendly interface, and students' likes and dislikes. Arias, Buitrago, and Pineda (2011) explored the implementation of virtual environments and its implications for teaching. Herrera (2017) conducted a research project in a public university in Colombia where a virtual learning environment (VLE) was implemented as a main tool in an English as a foreign language class. The results showed that students felt motivated but found that a lack of infrastructure and Internet connectivity posed a main barrier for VLE implementation. Other studies like the one conducted by Fandiño (2012) and Herrero, Marín, and González (2016) show that teachers need institutional support in order to acquire the necessary skills to innovate in their classrooms using ICTs. In their research study, Clavijo Olarte and Quintero (2012) show how the implementation of ICTs in pre-service teachers' education might serve a dual purpose: On the one hand, it could improve their English language development and on the other hand, serve as a pedagogical tool for their future professional life. 


\section{Mobile Learning (M-learning)}

As a concept in development, mobile learning or m-learning, does not have a unified definition. For Guy (2010), different alternatives have attempted to pin it down.

Firstly, it is a descendant of electronic learning or e-learning. Pinkwart, Hoppe, Milrad, and Perez (2003) and Georgiev, Georgieva, and Smrikarov (2004) describe it as a space that exists in the e-learning approach. On the other hand, there are some who support $\mathrm{m}$-learning as an individual discipline. Caudill (2007) cites different supporters of this new discipline such as Traxler (2005), who defines it as an educational outline where the use of technologies is the requirement or Trifonova and Ronchetti (2003), who define m-learning as the educational process that involves activities mediated by mobile tools.

Going deeper into m-learning, Ozdamli and Cavus (2011) establish some elements and characteristics we need to consider when talking about m-learning without depending on what we aim to do. The elements are: learner, who determines the needs, interest, and background in the educational process; teacher as an expert of the information presented; content which is decided with the comunity in order to make it interactive; environment as the place where the information is shared — the environment could be online or face to faceand finally, assesment as a tool to help the learner to know his/her process and clarify his or her doubts about the content.

In m-learning teachers have to pay special attention to how contents respond to the needs of the individuals and to their contexts. Alonso de Castro (2014) highlights the communicational features of m-learning, mainly "useful in the development of collaborative activities which help establish group work and help develop creativity and communicational skills among students" (p. 12).

\section{How We Walked This Road}

This small-scale research aimed at understanding how a pre-service teacher deals with the innovation of using technology in the English as a foreign language (EFL) classroom. To answer this question, we used an introspective method.

In psychology, introspection is defined as "learning about one's own currently ongoing, or perhaps very recent past, mental states or processes" (Schwitzgebel, 2016). On the other hand, Nunan (2010) defines introspection in research as the process where you observe and reflect on your own thoughts, feelings, cognitive processes, mental situations, and the way those elements determine your behavior.

The techniques used in this type of research are related to the analysis of some mental events, which have taken place sometime afterwards. There are different techniques to collect 
data in this method: think-aloud technique, anagram task, diary studies, logs, and journals. These techniques provide the researcher with some retrospective data (Nunan, 2010). Nevertheless, this kind of data has been strongly criticized because of the gap of time between the event and the report; some authors such as Nisbett and Wilson (1977) argued that the gap makes the data become unreliable but the advocates of the method such as Ericsson and Simon (1984) argue that is not easy for teachers to report their experiences and teach a class at the same time.

Given the importance of having the student-teacher voice first hand, for our study, in particular, we found that narrative introspection would serve our interest. Belk (2007) states that "narrative introspection involves autobiographically thinking through and or telling one's own story or various aspects of it" (p. 194). Additionally, in order to explore further some issues that came up in the introspective narrative, we used an introspection interview, following the same logic of the former, in order to focus on particular events and decisions that took place during the student-teacher teaching practicum.

\section{Setting and Participants}

One student-teacher and her advisor conducted this research over a period of one year and a half. The student-teacher had a dual role: on the one hand, she had to implement an innovation as a requirement for her teaching practicum. On the other hand, she had to systematize the results for her research seminar. She carried out her innovation in a public school in Bogotá, with students of eleventh grade over an academic year.

The advisor's role was to guide the student-teacher in the systematization of the innovation for her research seminar. While doing this and being aware of the many struggles the student-teacher was facing, both decided to conduct a small-scale project to document those struggles. To fulfill this purpose, the following instruments were used to collect data: An introspective narrative in which the student-teacher recalled her experience conducting the innovation. Both had many conversations previous to the writing of the narrative, and the advisor gave her some prompts to generate a rich written piece. After analyzing the narrative, the advisor conducted an introspective interview with the student-teacher to explore her tensions, concerns, dichotomies, opinions, and so on, while carrying out the innovation. As secondary data sources we used the lesson plans the student-teacher produced as part of the implementation of the innovation.

In this article we are reporting, in order to give context, the pedagogical intervention carried out by the student-teacher, and the research part, which was conducted by both the student-teacher and the advisor. 


\section{Trying Out News Things: The Pedagogical Intervention}

The idea of using m-learning was born out of the desire of the pre-service teacher to use a device that students had and used all the time: smartphones. Additionally, the pre-service teacher is passionate about technology and saw the pedagogical experience as an opportunity to introduce technology to make her classes more appealing. The classes were planned to be implemented during 20 lessons of two hours each, bearing in mind the development of the four skills as directed by the homeroom teacher.

Initially, the student-teacher followed the lesson plan guide provided by her university mentor and which followed the PPP method proposed by Harmer (2009) (presentation, practice, and production). As such she filled her lesson plans trying to put together her interests, her homeroom teacher's, and her university mentor (see Appendix 1).

The student-teacher selected apps that would help students in each one of the four skills: Perfect Viewer (for reading), Meme Generator (for writing), Free Viva Video (for speaking) and TuneIn Radio: Radio \& Music (for listening). For each app the pre-service teacher gave the students a task related to each of the skills. For reading, they should read a comic; for writing, create memes about a comic; for speaking, record a video about their perception of the comic; and for listening, listen and summarize a radio program in English. On the other hand, they would work cooperatively (groups were organized around the kind of cellphones they had).

In order to start the intervention, the pre-service teacher handed in the plan to the homeroom teacher but he said the project could not be implemented in the first half of the academic year because students should study for the national exam they should take in July 2016. Due to this, the pre-service teacher changed the plan to implement the project during the second semester of 2016.

At the beginning of the second semester of 2016, the classes were planned to be implemented during 16 weeks and each four weeks students would work with different apps. Unfortunately, the pre-service teacher found out that students were working on their final projects and she had to help them with the oral presentation in English. This situation made her plan change once again.

Once the homeroom teacher gave her approval to start the innovation the studentteacher started the implementation. First, she surveyed the type of cellphones her students had and grouped them around that. She explained how to use the different apps (to her surprise her students were not familiarized with this type of apps and did not have the skills to work with them).

She started using Perfect Viewser. The activity had to do with reading a comic strip of the Civil War by Marvel Comics. Students read in class and she helped them with vocabulary and 
grammar. This activity was interesting and some students asked her for the next comics to read at home. Then they were asked to write some memes about the comic in English; this was the most interesting activity for students because they were used to finding memes in their social networks and now they themselves knew how to create them (see some examples in Appendix 2).

Unfortunately given the short time the student-teacher had to conduct her project, she could not give feedback or make students correct their task. When the pre-service teacher wanted to implement the app for the speaking section students were close to the end of their school year and had to take final exams.

\section{What We Found: Living the Teaching Practicum Within Dichotomies}

After conducting the analysis of data, in order to answer the research question, we found that the student-teacher lives her practicum within dichotomies. This led us to identify three main ways she finds to deal with using technology as innovation in her teaching practicum: (a) Negotiating between epistemologies, (b) Making up for the logistical/technological flaws in the setting, and (c) Mending the self: Between frustration and achievement. In what follows, we will describe each one.

\section{Negotiating Between Epistemologies}

The student-teacher has to negotiate between the epistemology given during her undergraduate courses and her personal epistemology (Hofer, 2004). As stated by Cárdenas and Suárez-Osorio (2009), the teaching practicum should give student-teachers opportunities to develop their teaching abilities while understanding how teaching and learning take place. In grounding for her teaching practicum, one of the researchers (the student-teacher) took several courses on English teaching. These teaching methodologies, which present a Western view of teaching and learning, have been produced in the inner circle countries (Canagaragah, 2009) or in the epistemological North (De Soussa Santos, 2011) and have been consumed by the South. As shown in a recent study conducted by Castañeda-Trujillo (2016), teacher preparation programs in Colombia are still dominated (colonized) by the way English teaching is conceived by the North. As a consequence, there is a mismatch between what the methodology books say and what student-teachers encounter in their classrooms.

When reaching the point where our participant had to propose and carry out an innovation in a real school setting where she had to conduct her teaching practicum she faced an authentic context and realized that something goes between expectations and reality. Her 
epistemological negotiation took her in two directions: One has to do with the teaching of English; the other with the technology literacy of her students.

In terms of the teaching of English, she had to produce a lesson plan a week ahead of her class and had to follow the PPP model. After her lesson, she would have to fill in a reflective form (designed to deal with instrumental aspects only); in the one dated September 14th (see Appendix 3), she states that she managed to carry out only half of her class. Her plan was to teach students the use of an application to create cartoons. In her imaginary world - product probably of the teaching methodology books where settings are homogenized — her students would be well-behaved, engaged, middle class (to afford smartphones), and have technology literacy skills. But she found a totally different setting, so her first epistemological negotiation takes places within the class. She realizes that the PPP model would not work; that there should be other ways of learning and that she would have to put her lesson upside down and follow her instincts towards what she thought would work and listen to her students' needs. Here she privileges her personal epistemology—defined by Hofer (2004) as "theories and beliefs that individuals hold about knowledge and knowing, and the way in which such epistemological perspectives are related to academic learning" (p. 129)—over the given epistemology. In her lesson plans her main interest is grammatical; her concern is about the language per se, it is about "correcting mistakes" (Sept_7_16), "correcting pronunciation" (Sept_14_16), "phrasal verbs" (Oct_5_17), and the like. But in the actual classroom she switches her "grammar oriented" lesson to a truly meaningful one in which she makes on-the-spot decisions to serve her students' learning needs which go beyond the mere formal aspects of English. Here in her own words:

As they use the cellphone every day, I thought they could open the comic and read it easily but the next class I had a surprise, nobody were able to open the comic and read it. What I decided to do was to use half an hour of a class and taught them how to open the .cbr file because I thought I was not clear with the instruction, so I asked them to download the file and bring to the next class as some of them did not had Gmail account to access to the folder I decided to send the file again and I wrote some instructions about how to open the file. [sic] (Narrative Introspection)

In terms of technology literacy, she expected her students to become "digital natives" (Prensky, 2001) but she found that beyond using social media, the students in her course were not very proficient at using technology. She is aware that this lack of technology literacy will interfere with the development of her class and decides to stop, change gears, and teach them how to deal with the technological task.

Through the data collected (lesson plans, narrative introspection, and introspective interview) we can trace the struggles the student-teacher goes through. She complies with the design of a lesson plan that fulfills the requirement of the undergraduate program, as can be seen in Table 1, but once in the classroom facing the constraints of the context, instead 
of trying to carry out her lesson no matter what, she is proactive, sensitive to the needs of her students and adapts the lesson to reality, as shown in the excerpt above. This is consistent with Aguirre's (2014) finding on how pre-service teachers really care about their students and make the necessary things to help them both at the emotional and cognitive level.

Table 1. Lesson Plan, October 19th

\begin{tabular}{|c|c|c|c|c|}
\hline \multicolumn{5}{|c|}{$\begin{array}{l}\text { Objectives: } \\
\text { To solve questions about the topics for the final exam. }\end{array}$} \\
\hline Topic & Preparation & Activities & Time & Materials \\
\hline & Warming-up & $\begin{array}{l}\text { Students will organize three groups, each } \\
\text { group for a topic. They are going to think } \\
\text { about what they can explain for each topic. }\end{array}$ & $10 \mathrm{~min}$. & \\
\hline & Presentation & $\begin{array}{l}\text { The students will select two members who } \\
\text { will pass and explain the topic they have. } \\
\text { The classmates have to ask questions. }\end{array}$ & $30 \mathrm{~min}$. & \\
\hline & Practice & $\begin{array}{l}\text { The students will find in the teacher's } \\
\text { desk some bags with sentences on them. } \\
\text { They have to organize and tell the group } \\
\text { what the sentence is. Then they have to } \\
\text { create the tag question for each other. }\end{array}$ & $30 \mathrm{~min}$. & \\
\hline
\end{tabular}

\section{Making Up for the Logistics/Technological Flaws}

Student-teachers are required to carry out an innovation during their teaching practicum. For some, the obvious innovations involve the use of technology, as was the case of our participant who decided to incorporate m-learning into the English class. As reported by Viáfara (2011), many teachers and student-teachers that use or have used technology for the development of their lessons, have taught themselves. Our participant, as reported by her in the introspection, initially learned from her brother and from there she learned autonomously. The data analysis allowed us to conclude that the student-teacher had to make up for the logistics of her innovation. As stated above, in her imaginary, the participant anticipated a picture-perfect classroom where she would be able to implement her innovation without a problem. Reality showed her otherwise and caused her to make decisions to compensate for this flaw. The first obstacle she found was that the school had wi-fi but students were not allowed to use it (Viáfara, 2011). She wanted to go on with her plan (instead of giving up) so she resorted to her technological skills and found applications students could use without an Internet connection. 
At the moment of implementing the lesson, she had to sort out all the technological and logistics difficulties she did not anticipate. This required from her tremendous ability to keep the control of the group, ${ }^{3}$ to keep her students engaged, and to keep on teaching her class. As reported by her in the following excerpt, she gives away her power and invites her students to come up with possible solutions, that is, she truly involved them and gave them voice:

In that moment I did not have the projector. I had to explain step by step. They kept saying "no teacher, I can't open it" or "it didn't work". I had my cellphone and my tablet, so I said "let's make four groups; one group can use my tablet". Since I had not a vertical relationship with them, it was more horizontal, I said "well, what are we going to do? there is no way to do the activity, are we going to do it?" One of them said: "yes, teacher, sounds cool but how do we do it?" Then I told him: "But how do we get the file? I tried to do it through bluetooth and I couldn't, I tried to link my cell and but didn't work, the Tablet didn't work either", then he said: "teacher, I'm going out, I know where to get the wi-fi signal, I download the file and come back". He steped out and came back 10 minutes later with the file and we could open it. (Introspective Interview) ${ }^{4}$

One additional element here that is worth mentioning, considering the context of public schools in Bogotá, is the mutual trust built between the student-teacher and the student who requests to step out. This is particularly striking because they were both so engaged in achieving the task that there was no room for distrust; the student-teacher is not worried about her student fleeing the class and, in fact, he comes back with the technological problem solved.

\section{Mending the Self: Between Frustration and Achievement}

As stated by Castellanos (2013): "Pre-service teachers come into the English teaching profession with beliefs about teaching; sometimes they are aware of them, other times they are not" (p. 196). As stated by the student-teacher in the semi-structured interview, she had some beliefs about how her teaching practicum would be and had great expectations about the things she would do (see excerpt below). But when she gets into the actual practicum her beliefs do not match the reality. This mismatch leads her to the third way to deal with using technology as an innovation in her English language teaching (ELT) practicum, which is to mend the self, trying to make a bridge between her expectations and her achievements:

As a teacher having had the experience, at first it was with that spirit, the one we all had when we started the teaching practicum... with such a desire to amaze our students, to do a thousand things because one is fresh, just out of college and has that raws sensibility...but

Although a homeroom teacher is supposed to accompany student-teachers in the classroom, it is very common that student-teachers are by themselves in charge of the whole class. That was the case for our participant.

4 The original text was produced in Spanish. One of the authors (the interviewer) translated it into English. 
when one meets the reality is different. After the experience I realized that it was not going to be so so wow. (Introspective Interview)

The student-teacher had to adjust her plans to the reality she found, and conform to what was possible. It was very striking for her that students were not allowed to use the wi-fi connection. Anecdotal data (collected as the role of one of the authors as teacher educator) have shown that this is a very common situation in Colombian schools. Many teachers who want to use technology cannot do it because school administrators neither allow them to use the equipment provided by the government (computers, tablets, smart boards, and the like) nor give them access to the wi-fi connection, which is consistent with Viáfara's (2011) findings. Once confronted with this fact, the student-teacher plans ahead and explores other possibilities that allow her to carry out her innovation.

Her students' digital illiteracy was another aspect in which she had to mend her beliefs. As stated above she wrongly assumed that her students were digital natives but found out that she had overgeneralized and had to walk them through very "basic skills" as she calls it.

The lack of accompaniment by a university mentor and by the cooperating teacher also played a role in her need to mend the self. In the semi-structured interview, she expresses her frustration but despite this, she carries out her innovation the best she can: "This was not a very rigourous innovation and I did not have any advisor" (Introspective Interview).

Given the circumstances and the context she faces, the student-teacher becomes an independent decision-maker (Díaz Benavides, 2013). She weighs her limitations and possibilities and decides to keep on in order to bring her students a different and entertaining way of learning English. At the end of her experience she acknowledges her frustrations but also her achievements and the possibilities for the future.

\section{Conclusion}

This introspective study has allowed both of us, the student teacher and her advisor, to reflect on several aspects of the teaching practicum that are not included in the teaching methods books. First of all, on the lack of communication among homeroom teachers, student-teachers, and university mentors. Many of the struggles the student-teacher experienced stemmed from this disconnection because each had different purposes for the teaching practicum.

Second, having a glimpse of this student-teacher's experience with her practicum shows how distant theories are from actual contexts. For Prensky (2001), teenagers are "digital natives" but what we found, which is consistent with other studies (e.g., Bennett, Maton, \& Kervin, 2008) is that this group of students is very good at using social media but that their technological skills are really limited; this might be due to many reasons, among them the lack 
of access to technological resources and opportunities to apply ICT in meaningful contexts. This was very frustrating for the student-teacher and challenged her to find ways to teach them basic skills in order to carry out her innovation.

Third, teachers are constantly pushed to innovate and use ICTs in the classroom, but as this research effort shows (which is consistent with other research studies reported here) it takes more than just will to make it happen. Local government and school administration have a huge role in providing the necessary resources for teachers to innovate. Schools of education have their fair share too but must include in their plans of study courses that equip teachers in using ICTs.

Finally, schools of education have an urgent task in re-thinking the teaching practicum from a situated perspective that includes the voices of all stakeholders involved: studentteachers, homeroom teachers, and university mentors.

\section{References}

Aguirre, I. (2014). Exploring pre-service EFL teachers' beliefs about their roles in an elementary school classroom in regard to pedagogical and emotional aspects of students. HOW, 21(1), 26-41. https://doi.org/10.19183/how.21.1.13.

Alonso de Castro, M. G. (2014). Educational projects based on mobile learning. Education in the Knowledge Society (EKS), 15(1), 10-19.

Arias, L. D., Buitrago, Z. R., \& Pineda, C. (2011). ICT in the professional development of EFL teachers: Perceptions and challenges. Folios, 33(1), 25-42. https://doi.org/10.17227/012348 70.33folios 25.42 .

Barraza, A. (2005). Una conceptualización comprehensiva de la innovación educativa [A comprehensive conceptualization of educational innovation]. Innovación Educativa, 5(28), 19-31.

Belk, R. W. (Ed.). (2007). Handbook of qualitative research methods in marketing. Cheltenham, UK: Edward Elgar Publishing.

Bennett, S., Maton, K., \& Kervin, L. (2008). The 'digital natives' debate: A critical review of the evidence. British Journal of Educational Technology, 39(5), 775-786. https://doi.org/10.1111/ j.1467-8535.2007.00793.x.

Canagarajah, A. S. (2009). Resisting linguistic imperialism in English teaching. Oxford, UK: Oxford University Press.

Cárdenas, A., \& Suárez-Osorio, J. M. (2009). Pre-service teachers' knowledge base at La Salle university. HOW, 16(1), 113-130.

Castañeda-Trujillo, J. (2016, November). Unveiling ideological foundations in English language teacher education. Lecture presented at the XXII Symposium on Research in Applied Linguistics \& IV International Symposium on Literacies and Discourse Studies. Universidad Distrital Francisco José de Caldas, Bogotá, Colombia. 
Castañeda-Trujillo, J. (2017). Voices from the south: English language pre-service teachers contributions to ELTE. In H. Castañeda-Peña (Ed.), ELT Research Agendas I. Bogotá, CO: Universidad Distrital.

Castellanos, J. (2013). The role of English pre-service teachers' beliefs about teaching in teacher education programs. Profile: Issues in Teachers' Professional Development, 15(1), 195-206.

Castro, A. Y., \& López, S. F. (2014). Communication strategies used by pre-service English teachers of different proficiency levels. HOW, 21(1), 10-25. https://doi.org/10.19183/how.21.1.12.

Caudill, J. G. (2007). The growth of m-learning and the growth of mobile computing: Parallel developments. The International Review of Research in Open and Distance Learning, 8(2), 1-13. https://doi.org/10.19173/irrodl.v8i2.348.

Clavijo Olarte, A., \& Quintero, L. M. (2012). Una experiencia de formación inicial de docentes de inglés para la inclusión de las TIC en la enseñanza de lenguas [An experience of initial English teaching training incorporating ICT in language teaching]. Folios, (36), 37-49. https:/ / doi.org/10.17227/01234870.36folios37.49.

Cota, S. D., \& Ruiz-Esparza, E. (2012). Pre-service teachers' beliefs about language teaching and learning: A longitudinal study. Profile: Issues in Teachers' Professional Development, 15(1), 81-95.

Day, R. (n.d.). Models and the knowledge base of second language teacher education. University of Hawai'i Working Papers in ESL, 11(2), 1-13.

De Sousa Santos, B. (2011). Epistemologías del sur [Epistemologies of the South]. Utopía y Praxis Latinoamericana, 16(54), 17-39.

Díaz Benavides, D. M. (2013). The way student-teachers construct their identity at school. HOW, 20(1), 36-50.

Ericsson, K. A., \& Simon, H. A. (1984). Protocol analysis: Verbal reports and data. Cambridge, US: MIT Press.

Espitia, M. I., \& Kwinta, A. (2012). "Buddy System": A pedagogical innovation to promote online interaction. Profile: Issues in Teachers' Professional Development, 15(1), 207-221.

Fandiño, Y. J. (2012). The impact of ICT training through wikis on in-service EFL teachers: Changes in beliefs, attitudes, and competencies. HOW, 19(1), 11-32.

Flyvbjerg, B. (n.d.). Phronetic planning research: Theoretical and methodological reflections. Retrieved from http:/ / eureka.sbs.ox.ac.uk/4842/1/SSRN-id2278320.pdf.

Freeman, D., \& Johnson, K. E. (1998). Reconceptualizing the knowledge-base of language teacher education. TESOL Quarterly, 32(3), 397-417. https://doi.org/10.2307/3588114.

Galvis, H. A. (2011). Transforming traditional communicative language instruction into computer technology-based instruction: Experiences, challenges and considerations. Folios, 34(2), 93102. https://doi.org/10.17227/01234870.34folios93.102.

Georgiev, T., Georgieva, E., \& Smrikarov, A. (2004, June). M-learning: A new stage of e-learning. Paper presented at the International Conference on Computer Systems and Technologies: CompSys Tech 2004, Rousse, Bulgaria. https://doi.org/10.1145/1050330.1050437. 
Guy, R. (2010). Mobile learning: Pilot projects and initiatives. Santa Rosa, US: Informing Science Press.

Halverson, R. (2004). Accessing, documenting, and communicating practical wisdom: The phronesis of school leadership practice. American Journal of Education, 111(1), 90-121. https://doi. org/10.1086/424721.

Harmer, J. (2009). The practice of English language teaching (4th ed.). Harlow, UK: Longman.

Herrera, L. (2017). Impact of implementing a virtual learning environment (VLE) in the EFL classroom. Íkala, Revista de Lenguaje y Cultura, 22(3), 479-498. https://doi.org/10.17533/udea. ikala.v22n03a07.

Herrera, L. E., Cruz, M., \& Sandoval, M. A. (2014). Using personal portable devices as learning tools in the English class. HOW, 21(2), 74-93. https://doi.org/10.19183/how.21.2.5.

Herrero, R., Marín, V., \& González, I. (2016). Las tecnologías de la información y la comunicación como medio educativo para la adquisición de competencias profesionales del alumnado de educación superior [Information and communication technologies as educational means for the acquisition of professional skills in higher education students]. Diálogos Pedagógicos, 14(28), 23-40.

Hofer, B. K. (2004). Exploring the dimensions of personal epistemology in differing classroom contexts: Students' interpretations during the first year of college. Contemporary Educational Psychology, 29(2), 129-163. https://doi.org/10.1016/j.cedpsych.2004.01.002.

Huberman, A. M. (1973). Cómo se realizan los cambios en la educación: una contribución al estudio de la innovación. Paris, FR: UNESCO.

Kumaravadivelu, B. (2003). Beyond methods: Macrostrategies for language teaching. New Haven, US: Yale University Press.

Loughran, J., \& Hamilton, M. L. (Eds.). (2016). International handbook of teacher education. Singapore, SG: Springer Science and Business Media.

Macías, D. F., \& Sánchez, J. A. (2015). Classroom management: A persistent challenge for pre-service foreign language teachers. Profile: Issues in Teachers' Professional Development, 17(2), 81-99. https://doi.org/10.15446/profile.v17n2.43641.

Nisbett, R. E., \& Wilson, T. D. (1977). Telling more than we can know: Verbal reports on mental processes. Psychological Review, (84), 231-259. https://doi.org/10.1037/0033-295X.84.3.231.

Nunan, D. (2010). Research methods in language learning. Cambridge, UK: Cambridge University Press.

Ozdamli, F., \& Cavus, N. (2011). Basic elements and characteristics of mobile learning. Procedia Social and Behavioral Sciences, 28, 937-942. https://doi.org/10.1016/j.sbspro.2011.11.173.

Pinkwart, N., Hoppe, H. U., Milrad, M., \& Perez, J. (2003). Educational scenarios for the cooperative use of personal digital assistants. Journal of Computer Assisted Learning, 19(3), 383-391. https://doi.org/10.1046/j.0266-4909.2003.00039.x.

Prensky, M. (2001). Digital natives, digital immigrants: Part 1. On the Horizon, 9(5), 1-6. https:/ / doi. org/10.1108/10748120110424816. 
Quintero, A. H. (2016). Creating a pedagogical space that fosters the (re)construction of self through life stories of pre-service English language teachers. HOW, 23(2), 106-124. https:// doi.org/10.19183/how.23.2.293.

Rimari, W. (n.d.). La innovación educativa: un instrumento de desarrollo. Retrieved from http:// www.uaa.mx/direcciones/dgdp/defaa/descargas/innovacion_educativa_octubre.pdf.

Rogers, E. M. (1995). Diffusion of innovations (4th ed.). New York, US: The Free Press.

Roland, K., \& Beckford, C. (2010). Supporting associate teaching and mentoring of teacher candidates: Building a community of practice. Literacy Information and Computer Education Journal, 1(2), 153-162. https://doi.org/10.20533/licej.2040.2589.2010.0015.

Schwitzgebel, E. (2016). Introspection. In E. N. Zalta (Ed.), The Stanford Encyclopedia of Philosophy (Winter 2016). Stanford, US: Stanford University. Retrieved from https://plato.stanford. edu/archives/win2016/entries/introspection/.

Shulman, L. (1986). Those who understand: Knowledge growth in teaching. Educational Researcher, 15(2), 4-14. https://doi.org/10.3102/0013189X015002004.

Shulman, L. (1987). Knowledge and teaching: Foundations of the new reform. Harvard Educational Review, 57(1), 1-23. https://doi.org/10.17763/haer.57.1.j463w79r56455411.

Suárez, S. A., \& Basto, E. A. (2017). Identifying pre-service teachers' beliefs about teaching EFL and their potential changes. Profile Issues in Teachers' Professional Development, 19(2), 167-184. https://doi.org/10.15446/profile.v19n2.59675.

Traxler, J. (2005, June). Defining mobile learning. Paper presented at the IADIS International Conference on Mobile Learning, Qwara, Malta.

Trifonova, A., \& Ronchetti, M. (2003, November). Where is mobile learning going? Paper presented at the E-Learn 2003 Conference, Phoenix, USA.

Usma, J., \& Frodden, C. (2003). Promoting teacher autonomy through educational innovation. Íkala, Revista de Lenguaje y Cultura, 8(14), 101-132.

Viáfara, J. J. (2011). Reviewing the intersection between foreign language teacher education and technology. HOW, 18(1), 210-228.

\section{The Authors}

Sandra Viviana Pinzón Capador is a student-teacher at Universidad Distrital Francisco José de Caldas. Currently, she is working as an English teacher with kids from 3 to 5 years old.

Carmen Helena Guerrero Nieto is a full-time teacher in the PhD program in Education and the MA in Communication Education at the Universidad Distrital. Her publications are in critical pedagogy, bilingualism, and teacher education. She is the main researcher of the group Critical Studies on Educational Policies and serves as the vice-president of ASOCOPI. 


\section{Appendix 1: Pedagogical Experience and Research in Secondary I}

Grade: 1101

Session: 03

Topic: phrasal verbs

Objectives: To learn about the separable phrasal verbs

\begin{tabular}{|c|c|c|c|}
\hline Preparation & Activities & Time & Materials \\
\hline Warming-up & $\begin{array}{l}\text { The teacher will ask students how } \\
\text { was the last experience they had } \\
\text { working with it in the classroom. }\end{array}$ & $15 \mathrm{~min}$. & \\
\hline Presentation & $\begin{array}{l}\text { Then the teacher will teach students about } \\
\text { the phrasal verbs. The teacher will explain } \\
\text { that the students have to put a pronoun } \\
\text { between the verb and the preposition in } \\
\text { order to make it a separable phrasal verb. }\end{array}$ & $10 \mathrm{~min}$. & \\
\hline Practice & $\begin{array}{l}\text { The teacher is going to write on the } \\
\text { board some phrasal verbs, the students } \\
\text { do not know the meaning. Then students } \\
\text { will take a piece of paper on which they } \\
\text { have to create some sentences. First, they } \\
\text { create sentences with the meaning of the } \\
\text { verb they think about and the teacher } \\
\text { will check the grammar structure they } \\
\text { use. Then, they create a sentence with } \\
\text { the real meaning of the phrasal verbs. }\end{array}$ & $20 \mathrm{~min}$. & \\
\hline Production & $\begin{array}{l}\text { Students will listen to the song Locked Out of } \\
\text { Heaven by Bruno Mars. They will fill in the } \\
\text { blanks and highlight the phrasal verbs they } \\
\text { see in the song. Then they will guess the } \\
\text { meaning considering the context of the song. }\end{array}$ & $15 \mathrm{~min}$. & \\
\hline Closing & $\begin{array}{l}\text { The teacher will answer the questions } \\
\text { for the students and will ask for the } \\
\text { next app to be downloaded. }\end{array}$ & $10 \mathrm{~min}$. & \\
\hline
\end{tabular}


Sandra Viviana Pinzón Capador and

Carmen Helena Guerrero Nieto

Appendix 2: Memes Designed by the Students

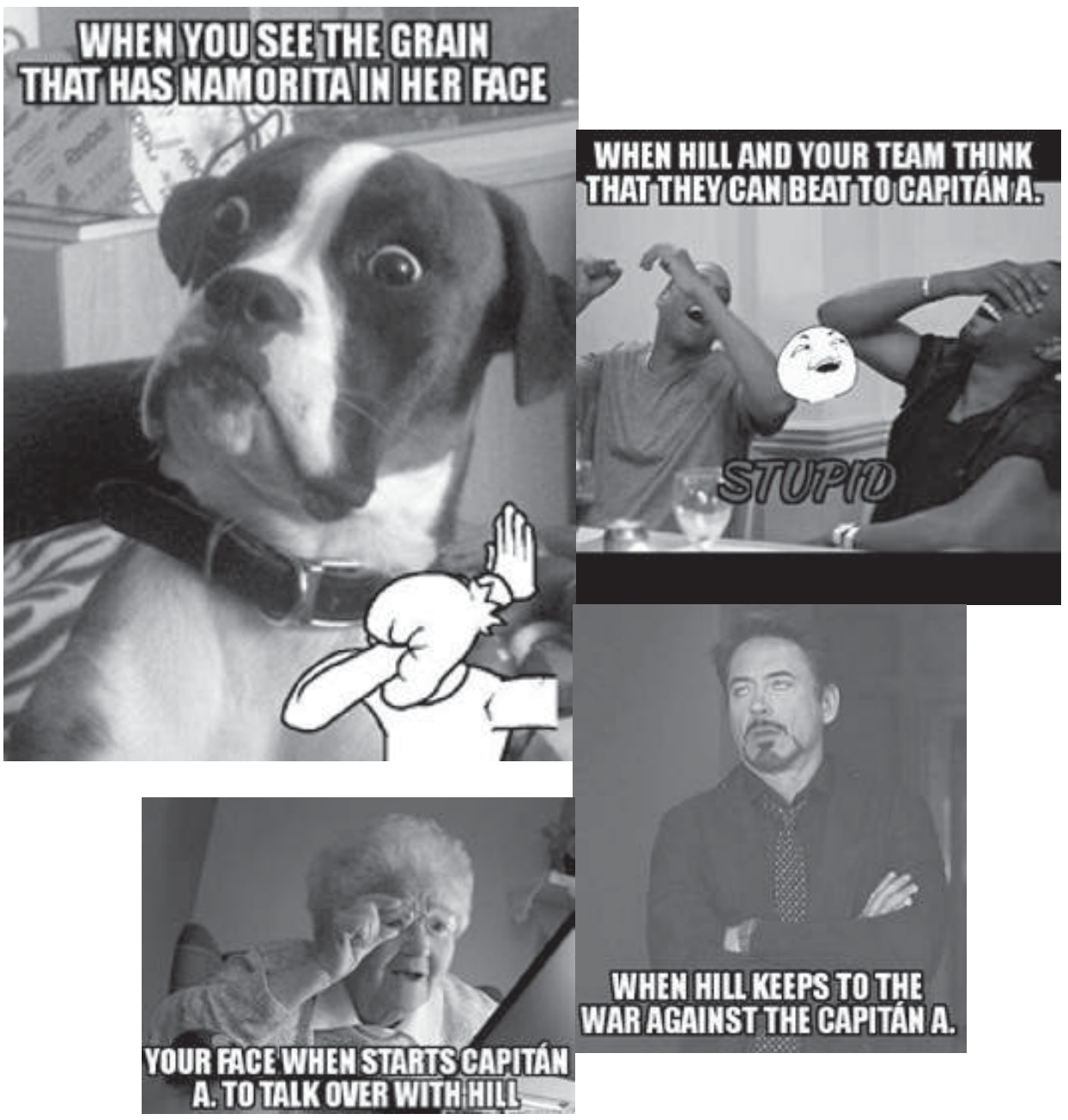




\section{Appendix 3: Pedagogical Experience and Research in Secondary I}

Grade: 1101

Session: 02

Topic: phrasal verbs

Objectives: To explain to students the inseparable phrasal verbs

\begin{tabular}{|l|l|l|l|}
\hline \multicolumn{1}{|c|}{ Preparation } & \multicolumn{1}{|c|}{ Activities } & Time & Materials \\
\hline Warming-up & $\begin{array}{l}\text { To collect ideas about the comic they } \\
\text { had to read for this class. The comic } \\
\text { was sent on the weekend. They have } \\
\text { to speak about it and compare it with } \\
\text { the movies that are related to it. }\end{array}$ & 15 min. & Presentation \\
\hline Practice & $\begin{array}{l}\text { Then the teacher presents the phrasal } \\
\text { verbs; in this class the teacher will explain } \\
\text { just the inseparables phrasal verbs (the } \\
\text { ones which cannot be divided). }\end{array}$ & 10 min. & \\
\hline Production & $\begin{array}{l}\text { The students will be divided into groups } \\
\text { of } 6 . \text { They have to create sentences } \\
\text { using the phrasal verbs but the sentences } \\
\text { should be related to the comic. If the } \\
\text { sentence has no relation, it will be wrong. }\end{array}$ & 20 min. & \\
\hline Closing & $\begin{array}{l}\text { The students have to create } 5 \text { memes } \\
\text { about the comic with the app asked } \\
\text { for this class (Meme Generator). } \\
\text { They will use the phrasal verbs. }\end{array}$ & 15 min. & \\
\hline
\end{tabular}

